\title{
Market Orientation Effects On Business School Performance: Views From Inside And Outside The Business School
}

Robert L. Webster, Ouachita Baptist University, USA

Kevin L. Hammond, University of Tennessee at Martin, USA

James C. Rothwell, Ouachita Baptist University, USA

\begin{abstract}
In the world of higher education, organizational strategies may take the form of a research, teaching, student-centered, comprehensive, or international strategy, just to name a few. This manuscript reports the results of a national survey examining the possible impacts of employing a market orientation strategy within schools of business and its possible impact on organizational performance. The schools researched are member business schools of the Association to Advance Collegiate Schools of Business (AACSB-International) and all of the schools studied are located in the United States. The respondents to the survey are academic vice-presidents (outsiders) and deans (insiders) of colleges and universities holding membership in AACSB. The academic vicepresidents were chosen as they are thought to hold the outside management position that can primarily affect the organizational strategy of the academic organizations under their purview. The deans of the business schools were selected as they represent the highest inside level of leadership. We use a reworded Narver and Slater (1990) "market orientation" scale and the Jaworski and Kohli's (1993) "overall performance" scale in the current research. One hundred sixteen academic vice-presidents and 131 business school deans responded to the survey. The manuscript details the data collection and analysis, statistical results, and implications for university leaders of business schools as well as other academic leaders.
\end{abstract}

Keywords: Business School Performance; Market Orientation; AACSB-International

\section{INTRODUCTION}

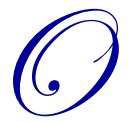

rganizations of all forms, including businesses, governmental organizations, and institutions of higher learning, seek to attain and maintain high levels of performance. A specific organizational strategy and/or culture may play an important role in achieving and maintaining a high level of organizational performance and, if this is true, it would be beneficial to be able to describe and then measure quantitatively such a strategy or culture. This research investigates these propositions and attempts to provide insight into how performance of AACSB member schools may be influenced or affected by a specific strategy. The specific strategy is a market orientation strategy.

Market orientation refers to an organizational culture in which everyone in the organization is committed to the customer and adapts in a timely manner to meeting the changing needs of the customer. It is further described as an organizational culture dedicated to providing superior customer value by successfully achieving a customer focus, acquiring competitor intelligence, and maintaining interfunctional coordination. Market orientation is viewed as the implementation of the marketing concept.

The idea that criteria for excellence in higher education should come from marketing concepts may seem revolutionary. However, the idea that organizations of higher education should employ marketing strategies to improve their performance appeared in the literature as early as the 1960s. Kotler and Levy (1969) were pioneers in 
successfully arguing for broadening the scope of marketing (and the marketing concept) to include higher education as well as other nonbusiness organizations.

Aspiring high performance business schools seek accreditation from AACSB. Their standards for business school accreditation outline requirements that, if met, lead to accreditation, thereby elevating the status of the school as well as indicating superior performance.

This paper reports the results of an empirical study concerning AACSB member business schools and their levels of market orientation and performance. Inputs from academic vice presidents and business school deans are used. In this study, the academic vice presidents represent the outsiders and the business school deans represent the insiders (see the paper title). The data were collected by mail from a national survey of AACSB member business schools (only those located in the United States were surveyed). Market orientation scores are used as the independent variables in this study. The research then investigates the impact of the independent variables on reported organizational performance, the dependent variable in the study.

\section{DISCUSSION AND LITERATURE REVIEW}

Excellence of performance in higher education is certainly important to government officials, university administrators, accrediting organizations, students, parents of students, and employers of students. Within many business schools, excellence is assessed and assured by the qualification standards of the bodies awarding formal accreditation to business schools (Karathanos \& Karathanos, 1996). For American business schools, the main accreditation body is AACSB. Performance is ranked more informally in the United States by the annual guides published by U.S. News and World Report and by the Peterson's web-based educational information resource, both directed at prospective students, their parents, and their advisers.

Additionally, the Baldrige National Quality Program (BNQP, 2005) for higher education incorporates behaviors and actions indicative of high levels of market orientation as described in the marketing literature (Kohli \& Jaworski, 1990; Narver \& Slater, 1990; Jaworski \& Kohli, 1993; Slater \& Narver, 1994; Webster, Hammond, \& Harmon, 2005; Hammond, Webster, \& Harmon, 2006; Webster, Hammond, \& Rothwell, 2010) throughout the education criteria for performance excellence. Further, the marketing literature (Barksdale \& Darden, 1971; Houston, 1986; Kohli \& Jaworski, 1990; Narver \& Slater, 1990; Jaworski \& Kohli, 1993; Siguaw, Brown, \& Widing, 1994) supports assertions by practitioner-oriented publications, such as the BNQP 2005, that these behaviors and actions result in a greater ability of the organization to achieve its objectives and attain higher levels of performance. The term "market orientation" refers to the extent that an organization employs the marketing concept. Kohli and Jaworski describe the processes required to engender market orientation as a "distinct form of sustainable competitive advantage" (1990). They state that market orientation consists of "the organization-wide generation, dissemination, and responsiveness to market intelligence" (1990). Narver and Slater agreed with Kohli and Jaworski, proposing three behavioral components (customer orientation, competitor orientation, and interfunctional coordination) that "comprehend the activities of marketing information acquisition and dissemination and the coordinated creation of customer value" (1990).

This research extends the previous research of Hammond et al. (2006), which provided a comparison of the market orientation components to criteria for performance excellence described in the BNQP 2005. We investigate the impact these organizational behaviors described in the market orientation literature, as well as the BNQP 2005, on the performance of AACSB member business schools as reported by their academic vice-presidents and business school deans.

\section{RESEARCH QUESTIONS}

The objectives of this study are to answer the following research questions:

1. Can existing scales be reworded and used to produce reliable and valid measurements of market orientation and overall performance in the context of the university setting? 
2. What are the mean levels of the three constructs of market orientation toward students as reported by academic vice-presidents and business school deans of colleges and universities whose business schools are members of AACSB?

3. How do the mean levels of market orientation of the vice-presidents and business school deans toward students compare to the levels of market orientation toward customers reported by specialty business managers, as catalogued in previous research conducted on businesses in the private sector?

4. What are the mean scores of the organizational performance scale reported by the academic vice-presidents and business school deans?

5. Do levels of reported market orientation toward students affect the level of reported organizational performance?

To address Research Question 1, we reworded Narver and Slater's (1990) market orientation scale. Narver and Slater explain that this scale, consisting of three behavioral components, is also consistent with the findings of Kohli and Jaworski (1990). The behavioral components of the scale include the activities described by Kohli and Jaworski (1990). The two sets of authors agreed that market orientation is continuous rather than dichotomous and, addressing concerns raised by Barksdale and Darden (1971), is properly measured in terms of behaviors and activities instead of "philosophical notions." Accordingly, the Narver and Slater measure consists of several questions addressing specific behaviors and activities that, together, measure the extent that the organization (or organizational unit) applies the marketing concept. The market orientation scale of Narver and Slater is reworded as necessary and applied to the students. The survey is discussed more fully in the Methodology section of this paper.

"Overall performance" is measured using the Jaworski and Kohli (1993) two-item measure that is based on executive opinion of performance. This subjective measure incorporates differences in performance goals that exist from school to school by simply requesting the vice-presidents and business school deans indicate the recent overall performance of their business schools, from poor to excellent. The wide range of possible performance goals is not assumed in the survey for any of the schools but is left for the respondent to decide which goals should influence their responses. Each respondent should answer the questions about actual overall performance relative to the expectations and performance goals of the business school. Slater and Narver (1994) echo Jaworski and Kohli's defense of the use of subjective performance measures, noting that the measures "are used commonly in research on private companies or business units of large corporations." Slater and Narver (1994) also noted the "strong correlation between subjective assessments and their objective counterparts" found in previous business research.

Research Question 1 is addressed through psychometric analysis of the scales. The scales and their development are more fully discussed in the Methodology section of this paper and the psychometric analysis is addressed in the Results section.

To answer Research Question 2, the reported market orientation mean scores of the vice-presidents and the business school deans are calculated for the three dimensions of market orientation (customer orientation, competitor orientation, internal coordination, and also for overall market orientation-the numerical average of the other three).

To answer Research Question 3, the mean scores of the vice-presidents and business school deans are compared to the mean scores of specialty business managers, as reported by Narver and Slater (1990). The general hypotheses were than there were no differences between the market orientation scores of the business managers and the vice-presidents and the business school deans. These hypotheses were tested by way of a series of t-tests that compared mean scores of the vice-presidents and the deans to those of the business managers. For each comparison, $\mathrm{t}$-tests were conducted separately on the four components of market orientation.

To answer question 4, the mean scores of the performance scale are computed from the inputs from the academic vice-presidents and the business school deans.

To address question 5, regression models are constructed and analysis of variance of the regression models is undertaken to determine if the independent variables - those being the three constructs of market orientation (customer orientation, competitor orientation, and interfunctional coordination) - have a significant statistical effect on the dependent variable - organizational performance. 


\section{METHODOLOGY}

Data for the study were collected by way of a mailed survey. Survey instruments, along with a cover letter, were mailed to business school deans and academic vice-presidents of schools of business located in the United States holding membership in AACSB-International. As key informants (Campbell, 1995; Phillips, 1981), the vicepresidents and the deans were asked to complete the survey and return it in a business reply envelope that was provided. Of the total survey instruments mailed, 116 were completed and returned by the vice-presidents and 131 were completed and returned by the business school deans. The response rate was approximately $23 \%$. Data for market orientation and for overall performance of the business schools were gathered from the respondents through the use of scales mentioned above. Churchill (1979) suggests that the appropriateness of scales borrowed from other studies needs to be addressed before survey research is accomplished. Therefore, all our scale items were pre-tested before mailed. We first consulted with several vice-presidents, deans, chairs, and other university administrators. These consultations resulted in a cover letter that more clearly defined the purpose of the research and caused a slight rewording of several of the survey questions.

To measure market orientation, we chose Narver and Slater's (1990) construct (MKTOR), which consists of several questions addressing specific behaviors and activities which, together, measure the extent that the organization (the business school in this case) applies the marketing concept. The scale addresses concerns raised by Barksdale and Darden (1971) that market orientation is properly measured in terms of behaviors and activities instead of "philosophical notions." A seven-point response scale is used, ranging from one (1) "not at all" to (7) "to an extreme extent." Scores above the midpoint (4.0) indicate application by the respondent of the marketing concept; scores below the midpoint indicate a lack of application by the respondent. Questions from the original scale were somewhat modified to conform to the vocabulary prevalent in academic institutions and to avoid referring to students as "markets" or "customers." We combine the questions to form three subscales that measure the market orientation components (customer orientation, competitor orientation, and interfunctional coordination), matching Narver and Slater's methodology. The subscales combine to form an overall measure of market orientation, also matching Narver and Slater's methodology. Fifteen questions were used in the collection of the market orientation data. The questions and explanatory information about the survey questions may be found in Appendix 1.

"Overall performance" is measured using the subjective Jaworski and Kohli (1993) two-item measure that is based on executive opinion of performance. No specific performance goals are assumed for the respondents. Each respondent is requested to answer the two questions about actual recent overall performance relative to the expectations and performance goals of their organization - in this case, the business school. Possible responses on the seven-point scale range from poor (1) to excellent (7). The questions and explanatory information about the survey questions may be found in Appendix 2. Slater and Narver (1994) defend the use of subjective performance measures, noting that the measures "are used commonly in research on private companies or business units of large corporations" as well as the "strong correlation between subjective assessments and their objective counterparts" indicated in previous research.

The possibility of non-response bias was investigated by comparing early and late respondents (Armstrong \& Overton, 1977). The tests indicated no significant differences between early and late respondents (at the 10 level of significance). Also, Berdie (1989) found that, even in the event of non-response bias in mail surveys, typically the bias did not alter the survey findings. We proceeded on the basis that significant non-response bias did not exist.

Narver and Slater (1990) reported market orientation scores for three separate types of businesses commodity, specialty, and distribution. The authors believe schools of business demonstrate more of the characteristics of specialty businesses than the characteristics of the commodity or distribution businesses. The commodity and distribution businesses in the Narver and Slater study produced and sold generic products designed for a wide range of customers. The specialty business firms produced and sold products that were individualized (relative to the commodity products) for specific customer orders. By adapting its generic or base product, the specialty products firm creates superior value and thereby provides more benefit to the customer. This type of firm is challenged to constantly monitor the competitive environment and to be vigilant for changes in the customer requirements. Likewise, AACSB-International schools of business seek to provide a product that is individualized 
through its programs of study or majors. AACSB-International schools would argue that a superior product (relative to non-member schools) is provided that would benefit its customers (or students). We therefore used the market orientation scores for specialty business, as reported by Narver and Slater (1990), for our comparisons.

\section{RESULTS}

After receiving the completed surveys from the respondents, the reworded Narver and Slater scale was subjected to reliability analysis, exploratory factor analysis, and confirmatory factor analysis (Wheaton, Muthen, Alwin, \& Summers, 1997; Bentler \& Bonett, 1980; Marsh \& Hocevar, 1985; Bentler, 1990; Browne \& Mels, 1992; Browne \& Cudeck, 1993). Results of these analyses indicated satisfactory reliabilities ranging from .73 to .91 , satisfactory item-to-total correlations ranging from 0.4 to 0.8 , exploratory factor loadings ranging from 0.5 to 0.8 , and confirmatory factor loadings ranging from 0.36 to 0.82 . Additionally, the confirmatory factor analysis demonstrated generally acceptable fit. These test results included comparative fit index measures ranging from .784 to 1.000 , a Tucker-Lewis index ranging from .702 to 1.000, and the CMIN/DF ranging from 2.05 to 2.56 . The RMSEA low values at the $90 \%$ confidence interval fell below 0.10 for all scales. The Pearson correlation coefficient for the two-item overall performance scale was computed to be 709 (sign. .000), indicating reliability for this two-item scale. These results indicate that Research Question 1 may be answered in the affirmative.

Tables 1 and 2 present the mean score and standard deviation for the three market orientation constructs and the mean score and standard deviation for the overall market orientation score (the arithmetic average of the three component scores), as well as the mean score and standard deviation for the performance indicator. Scores in Table 1 are from business school deans and scores in Table 2 are from academic vice-presidents. The information in these two tables provides answers to Research Questions 2 and 4.

Table 1: Mean Scores for Market Orientation Constructs (3) and Performance Indicator for AACSB Deans

\begin{tabular}{|l|c|c|c|}
\hline \multicolumn{1}{|c|}{ Description } & Mean & Std. Dev. & $\mathbf{N}$ \\
\hline MO- Customer & 4.550 & 1.056 & 131 \\
\hline MO- Competition & 3.711 & 1.130 & 131 \\
\hline MO - Coordination & 4.133 & 1.072 & 131 \\
\hline PERFORMANCE & 5.319 & 0.897 & 131 \\
\hline
\end{tabular}

Table 2: Mean Scores for Market Orientation Constructs (3) and

Performance Indicator for AACSB Academic Vice -Presidents

\begin{tabular}{|l|c|c|c|}
\hline \multicolumn{1}{|c|}{ Description } & Mean & Std. Dev. & N \\
\hline MO- Customer & 4.775 & 0.880 & 116 \\
\hline MO- Competition & 4.168 & 1.021 & 116 \\
\hline MO - Coordination & 4.441 & 1.003 & 116 \\
\hline PERFORMANCE & 5.295 & 1.017 & 116 \\
\hline
\end{tabular}

Tables 3 and 4 present the results of four separate t-tests undertaken to determine if statistically significant differences exist between the mean scores associated with the components of market orientation of business managers, school deans, and academic vice-presidents. As can be seen in the tables, the business managers reported higher levels for each of the three constructs as well as for overall market orientation. The business managers reported higher scores in absolute terms than did the deans and vice-presidents in each of the four measurements. Table 3 shows statistically significant differences in all four categories between the business managers and the school deans. In Table 4, three of the four t-tests between business managers and academic vice-presidents were found to be different by a statistically significant margin. The information in Tables 3 and 4 answer Research Question 3. 
Table 3: Means and T-Test Results for Business School Deans versus Specialty Business Managers Market Orientation Measurements (7-Point Scale)

\begin{tabular}{|l|c|c|}
\hline \multicolumn{1}{|c|}{ Market Orientation Construct } & $\begin{array}{c}\text { Business Mangers } \\
(\mathbf{n = 7 5})\end{array}$ & $\begin{array}{c}\text { Business Deans } \\
(\mathbf{n}=\mathbf{1 3 1})\end{array}$ \\
\hline Customer Orientation & 5.05 & $4.55^{*}$ \\
\hline Competitor Orientation & 4.71 & $3.71^{*}$ \\
\hline Interfunctional Coordination & 4.53 & $4.13^{*}$ \\
\hline Overall Market Orientation & 4.77 & $4.13^{*}$ \\
\hline
\end{tabular}

* significant at .01 compared to Business Managers

Table 4: Means and T-Test Results for Academic Vice-Presidents versus Specialty Business Managers Market Orientation Measurements (7-Point Scale)

\begin{tabular}{|l|c|c|}
\hline \multicolumn{1}{|c|}{ Market Orientation Construct } & $\begin{array}{c}\text { Business Mangers } \\
(\mathbf{n = 7 5})\end{array}$ & $\begin{array}{c}\text { Academic VP's } \\
(\mathbf{n}=\mathbf{1 1 6}) .\end{array}$ \\
\hline Customer Orientation & 5.05 & $4.78^{*}$ \\
\hline Competitor Orientation & 4.71 & $4.17^{*}$ \\
\hline Interfunctional Coordination & 4.53 & 4.44 \\
\hline Overall Market Orientation & 4.77 & $4.46^{*}$ \\
\hline
\end{tabular}

* significant at .05 compared to Business Managers

The regression models developed to answer Research Question 5 were:

Multiple Regression Models

$Y=b_{o}+b_{1} x_{1}+b_{2} x_{2}+b_{3} x_{3}$ where:

$\mathrm{Y}=$ mean score of the two-item performance scale as reported by the (1) academic vice-presidents and (2) business school deans

$\mathrm{b}_{0}=$ intercept

$\mathrm{x}_{1}=$ mean score of the customer orientation construct as reported by the (1) academic vice-presidents and (2) business school deans

$\mathrm{x}_{2}=$ mean score of the competitor orientation construct as reported by the (1) academic vice-presidents and (2) business school deans

$\mathrm{x}=$ mean score of the interfunctional coordination construct as reported by the (1) academic vice-presidents and (2) business school deans

Simple Regression Models

$\mathrm{Y}=\mathrm{a}+\mathrm{b}_{1} \mathrm{x}_{1}$ where:

$\mathrm{Y}=$ mean score of the two-item performance scale as reported by the (1) academic vice-presidents and (2) business school deans

$\mathrm{a}=$ intercept

$\mathrm{x}_{1}=$ mean score of the customer orientation construct as reported by the (1) academic vice-presidents and (2) business school deans

The simple regression models were constructed for two specific reasons. First, as will be seen later, the coefficients of the customer orientation constructs in the multiple regressions were found to be statistically significant. Secondly, as was mentioned earlier in the paper, a mean score above the midpoint of the scale (4.0 in this case) is indicative of the application of the marketing concept. For both the academic vice-presidents and the business school deans, the customer orientation construct was greater than 4.0, and these were the highest mean scores of the three constructs.

Tables 5, 6, 7, and 8 present the results of the analysis of variance of the two regression equations and yield that both the regression models are statistically significant in that both show that organizational performance is 
positively affected by higher market orientation scores in the first instance and singularly by customer orientation scores in the case of the simple regression. These two models and the analysis that follow provide insight and answers to Research Question 5.

Table 5: F-Test Results for Market Orientation Component Scores Effect on Performance - AACSB Business School Deans ( $N=131$ )

\begin{tabular}{|l|c|c|}
\hline \multicolumn{1}{|c|}{ Description } & F-Value & Significance \\
\hline Model & 14.261 & .000 \\
\hline MO - Customer & 15.395 & .000 \\
\hline MO - Competition & 1.551 & .215 \\
\hline MO - Coordination & 1.269 & .262 \\
\hline
\end{tabular}

$* \mathrm{R}$ Squared $=.252($ Adjusted $\mathrm{R}$ Squared $=.234)$

Table 6: F-Test Results for Market Orientation Score toward Customer Effect on Performance - AACSB Business School Deans ( $N=131)$

\begin{tabular}{|l|c|c|}
\hline \multicolumn{1}{|c|}{ Description } & F-Value & Significance \\
\hline Model & 42.848 & .000 \\
\hline MO - Customer & 42.848 & .000 \\
\hline
\end{tabular}

$* \mathrm{R}$ Squared $=.244($ Adjusted $\mathrm{R}$ Squared $=.238)$

Table 7: F-Test Results for Market Orientation Component Scores Effect on Performance - AACSB Business School VPs of Academics $(\mathbf{N}=116)$

\begin{tabular}{|l|c|c|}
\hline \multicolumn{1}{|c|}{ Description } & F-Value & Significance \\
\hline Model & 15.572 & .000 \\
\hline MO - Customer & 13.953 & .000 \\
\hline MO - Competition & 1.240 & .268 \\
\hline MO - Coordination & 1.920 & .169 \\
\hline
\end{tabular}

$* \mathrm{R}$ Squared $=.310($ Adjusted $\mathrm{R}$ Squared $=.290)$

Table 8: F-Test Results for Market Orientation Score toward Customer Effect on Performance - AACSB Business School VPs of Academics $(\mathrm{N}=116)$

\begin{tabular}{|l|c|c|}
\hline \multicolumn{1}{|c|}{ Description } & F-Value & Significance \\
\hline Model & 45.555 & .000 \\
\hline MO - Customer & 45.555 & .000 \\
\hline
\end{tabular}

$* \mathrm{R}$ Squared $=.297$ (Adjusted R Squared $=.290)$

The results of the study show that higher levels of market orientation do have a positive effect on organizational performance. In the case of the academic vice-presidents, the explanatory power of the model was slightly greater than for the business school deans. Both the academic vice-presidents and the business school deans rated the overall performance above 5 on a 7-point scale. Although the deans rated the business school performance slightly higher than did the academic vice-presidents, there was no statistical difference in the mean scores of 5.319 for the deans and 5.295 for the vice-presidents. This seems to indicate that both groups interpreted the performance of their business schools quite similarly.

\section{IMPLICATIONS}

This research finds that a market orientation strategy can positively impact business school performance, at least as reported by academic vice-presidents and business school deans. In both the simple and multiple regressions, the customer orientation construct was significant in explaining reported levels of business school performance. Additionally, in the multiple regressions, the models demonstrate that the three components of market orientation were, together, statistically significant in explaining changes in performance. The research findings also point out that businesses perceive a greater importance and have made greater progress in the implementation of the marketing concept vis-à-vis university schools of business as perceived by their academic vice-presidents and business school deans. This research found, as has previous research conducted on business organizations, that organizations may improve their performance by increasing levels of market orientation. 
The academic vice-presidents and business school deans reported lower levels of market orientation in their organizations than did their business counterparts. This may signal that the vice-presidents and deans are either not familiar with the marketing concept, customer and market orientation, or reject the idea that students are customers of the school, or all of the above. However, a significant opportunity would seem to exist to improve business school performance for schools that will put more effort into customer and market orientation. As students of the university may be viewed as the most visible of the numerous markets served, customer and market orientation efforts focused at students would seem to have the potential for the fastest and highest payoff. Examples of such payoffs, all of which might correctly be viewed as performance indicators, might include: 1) an increase in enrollment within the business school, 2) an increase in the hit rate (increase in percent of applicants that actually enroll), 3) an increase in the number of business majors, 4) an increase in the retention rate of current business students, and 5) an increase in business school graduation rates.

In view of Narver and Slater's (1990) and Kohli and Jaworski's (1993) findings that enhanced levels of market orientation will improve the competitive advantage of organizations, business schools appear to be organizations ripe to take advantage of the market orientation concept. Focus on creating a market orientation culture should serve both schools and their various stakeholders - not just students - in more effectively achieving business school objectives.

Our conclusions are tempered by the findings of Noble, Sinha, \& Kumar (2002) and Haugland, Myrtveit, \& Nygaard (2007) that there appears to be no single strategic orientation that leads to superior performance in every case and, as previously stated, building a market orientation culture within an organization is not a quick fix but rather a continuous process.

\section{FUTURE RESEARCH}

The research we report leaves open several related areas of interest for study. For example, future studies might include research to determine the impact or influence that variables, such as size of a school, school affiliation (AACSB, ACBSP, or neither), admission standards, placement efforts, or recruiting efforts, have on market orientation. Also, research on other stakeholders, such as parents of students, employers of students, and alumni associated with schools of business, would be useful. Such research would further our understanding of the market orientation construct and its application to higher education. Additional research in organizational culture, including that of market orientation, should be conducted in other non-profit organizations, such as governmental agencies that provide services to the public.

\section{AUTHOR INFORMATION}

Robert Webster, Ouachita Baptist University, is chairperson of the accounting department and is holder of the George Young Chair of Business. He is a past president of the Southwest Region of the American Accounting Association. His research interests are in behavioral studies in business and business education. E-mail: websterb@obu.edu (Corresponding author)

Kevin Hammond, University of Tennessee at Martin, is a professor of marketing and also serves as the Graduate Program Advisor at UT-Martin. He is widely published in the marketing literature with his most recent research dedicated to the subject of market orientation within higher education. E-mail: khammond@utm.edu

James Rothwell, Ouachita Baptist University, serves as the assistant dean of the school of business. He is a certified public accountant and has served in numerous audit positions. Email: rothwellj@obu.edu

\section{REFERENCES}

1. Armstrong, J. S., \& Overton, T. S. (1977). Estimating nonresponse bias in mail surveys. Journal of Marketing Research, 14(August), 396-402.

2. Barksdale, H. C., \& Darden, B. (1971). Marketers attitude toward the marketing concept. Journal of Marketing, 35(October), 29-36. 
3. Bentler, P. M. (1990). Comparative fit indexes in structural models. Psychological Bulletin, 107, 238-246.

4. Bentler, P. M., \& Bonett, D. G. (1980). Significance tests and goodness of fit in the analysis of covariance structures. Psychological Bulletin, 88, 588-606.

5. Berdie, D. (1989). Reassessing the value of high response rates to mail surveys. Marketing Research, 1, 5264.

6. BNQP (2005). Baldrige education criteria for performance excellence. Baldrige National Quality Program. Retrieved from www.quality.nist.gov/Education_Criteria.htm

7. Browne, M. W., \& Cudeck, R. (1993). Alternate ways of assessing model fit. In K. A. Bollen, \& K. S. Long (Eds.) Testing structural equation models (pp. 136-162). Newbury Park, California: Sage.

8. Browne, M. W., \& Mels, G. (1992). RAMONA user's guide. The Ohio State University, Columbus, Ohio.

9. Churchill, G. A. (1979). A paradigm for developing better measures of marketing constructs. Journal of Marketing Research, 16(February), 64-73.

10. Dwyer, F. R., \& Welsh, M. A. (1985). Environmental relationships of the internal political economy of marketing channels. Journal of Marketing Research, 22(November), 397-414.

11. Felton, A. P. (1959). Making the marketing concept work. Harvard Business Review, 37,(July-August), 5565.

12. Hammond, K. L., Webster, R. L., \& Harmon, H. A. (2006). Market orientation, top management emphasis, and performance within university schools of business: Implications for universities. Journal of Marketing Theory and Practice, (Winter), 14(1), 69-85.

13. Haugland, S. A., Myrtveit, I., \& Nygaard, A. (2007). Market orientation and performance in the service industry: A data envelopment analysis. Journal of Business Research, 60(11), 1191-1197.

14. Houston, F. S. (1986). The marketing concept: What it is and what it is not. Journal of Marketing, 50(April), 81-87.

15. Hunt, S. (1990). Commentary on an empirical investigation of a general theory of marketing ethics. Journal of the Academy of Marketing Science, 18(Spring), 173-177.

16. Jaworski, B. J., \& Kohli, A. K. (1993). Market orientation: Antecedents and consequences. Journal of Marketing, 57(July), 53-70.

17. Karathanos, D., \& Karathanos, P. (1996). The Baldridge education pilot criteria 1995: An integrated approach to continuous improvement in education. Journal of Education for Business, 71(May/June), 272276.

18. Kohli, A. K., \& Jaworski, B. J. (1993). Market orientation: The construct, research proposition, and managerial implications. Journal of Marketing, 54(April), 1-18.

19. Kotler, P. (1980) Marketing management: Analysis, planning and control (4th ed.). Englewood Cliffs, NJ: Prentice-Hall, Inc.

20. Larson, R., \& Catton, W., Jr. (1959). Can the mail-back bias contribute to a study's validity? American Sociological Review, XXIV, 243-245.

21. Levitt, T. (1969). The marketing mode. New York: McGraw-Hill Book Company.

22. Marsh, H. W., \& Hocevar, D. (1985). Applications of confirmatory factor analysis to the study of selfconcept: first - and higher-order factor models and their invariance across groups. Psychological Bulletin, 97, 562-582.

23. McNamara, C. P. (1972). The present status of the marketing concept. Journal of Marketing, 36(January), 50-57.

24. Morse, R. J., \& Flanigan, S. M. (2000). America's best colleges-how we rank them. U.S. News and World Report, (September 11), 104-105.

25. Narver, J. C., Park, S. Y., \& Slater, S. F. (1992). Market orientation, information, and marketing strategies. American Marketing Association Summer Educators Conference.

26. Narver, J. C., \& Slater, S. F. (1990). The effect of a market orientation on business profitability. Journal of Marketing, 54(October), 20-35.

27. Noble, C. H., Sinha, R. J., \& Kumar, A. (2002). Market orientation and alternative strategic orientations: A longitudinal assessment of performance implications. Journal of Marketing, 66(October), 25-39.

28. Peterson's Guide to Four Year Colleges, 2001, 31st ed. (2000). Lawrenceville, NJ: Peterson's/Thomson Learning.

29. Siguaw, J. A., Brown, G., \& Widing, R. E., II (1994). The influence of the market orientation of the firm on sales force behavior and attitudes. Journal of Marketing Research, 31(February), 106-116. 
30. Slater, S. F., \& Narver, J. C. (1994). Does competitive environment moderate the market orientationperformance relationship? Journal of Marketing, 58(January), 46-55.

31. Webster, R. L., Hammond, K. L., \& Harmon, H. A. (2005). Comparing market orientation culture of businesses and schools of business: An extension and refinement. Psychological Reports, 96, 377-382.

32. Webster, R. L., Hammond, K. L., \& Rothwell, J. C. (2010). Customer and market orientation within AACSB member business schools: Comparative views from three levels of administrators. American Journal of Business Education, 3(7), 79-91.

33. Wheaton, B., Muthen, B., Alwin, D. F., \& Summers, G. F. (1977). Assessing reliability and stability in panel models. In D. R. Heise (Ed.). Sociological methodology 1977 (pp.84-136). San Francisco: JosseyBass. 


\section{APPENDIX 1}

\section{Market Orientation Survey Questions Sent to Academic Vice-Presidents and Business School Deans of AACSB Schools}

1. Our objectives are driven by satisfaction of our students.

2. We measure satisfaction of our students systematically and frequently.

3. Those responsible for recruiting students regularly share information within our business school/institution concerning competitor's strategies.

4. Our market strategies (such as recruiting and retention) are driven by our understanding of the possibilities for creating value for our students.

5. We respond rapidly to competitive actions that threaten us.

6. We constantly monitor our level of commitment and orientation to students.

7. University administration regularly discusses competitors' strengths and strategies.

8. All levels of administration understand how the entire institution can contribute to creating value for students.

9. We give close attention to service of students after enrollment.

10. Our strategy for competitive advantage is based on our understanding of our students' needs.

11. We encourage other staff and faculty outside of recruiting/administration to meet with our prospective students.

12. All of our departments are responsive to and integrated in serving students.

13. Information on recruiting successes and failures is communicated across functions in the business school/institution.

14. We share information and coordinate resource use with other units in the institution.

15. We target potential students where we have, or can develop, a competitive advantage.

Each question is answered on a 7-point scale: $1=$ Not At All, $7=$ To an Extreme Extent. Questions 1, 2, 4, 6, 9, and 10 relate to the Customer Orientation construct/dimension; Questions 3, 5, 7, 11, and 15 relate to the Competitor Orientation; Questions 8,12,13, and 14 relate to Organizational Coordination. The Overall Marketing Orientation score is computed by averaging the mean scores of the other three sets of questions. 


\section{APPENDIX 2}

\section{Performance Measurement Questions Sent to Academic Vice-Presidents and Business School Deans of AACSB Schools}

1. Overall performance of the school of business last year was

2. Overall performance of your school of business relative to major competitors last year was

Both questions are answered on a 7-point scale: $1=$ Poor, $7=$ Excellent. 